\title{
mRNA expression of steroidogenic enzymes, steroid hormone receptors and their coregulators in gastric cancer
}

\author{
BARTOSZ ADAM FRYCZ ${ }^{1}$, DAWID MURAWA ${ }^{2,3}$, MACIEJ BOREJSZA-WYSOCKI ${ }^{4}$, \\ MATEUSZ WICHTOWSKI ${ }^{2}$, ARKADIUSZ SPYCHAŁA ${ }^{2}$, RYSZARD MARCINIAK $^{4}$, \\ PAWEŁ MURAWA ${ }^{2}$, MICHAŁ DREWS ${ }^{4}$ and PAWEŁ PIOTR JAGODZIŃSKI ${ }^{1}$ \\ ${ }^{1}$ Department of Biochemistry and Molecular Biology, Poznań University of Medical Sciences, 60-781 Poznań; \\ ${ }^{2}$ First Department of Surgical Oncology and General Surgery, Greater Poland Cancer Centre, 61-866 Poznań; \\ ${ }^{3}$ Research and Development Centre, Regional Specialist Hospital of Wrocław, 51-124 Wrocław; \\ ${ }^{4}$ Department of General and Endocrine Surgery and Gastroenterological Oncology, Heliodor Święcicki Clinical Hospital, \\ Poznań University of Medical Sciences, 60-355 Poznań, Poland
}

Received July 12, 2016; Accepted December 12, 2016

DOI: $10.3892 / \mathrm{ol} .2017 .5881$

\begin{abstract}
Epidemiological and experimental findings suggest that the development of gastric cancer (GC) is regulated by steroid hormones. In postmenopausal women and older men, the majority of steroid hormones are produced locally in peripheral tissue through the enzymatic conversion of steroid precursors. Therefore, using reverse transcription-quantitative polymerase chain reaction analysis, the mRNA expression of genes encoding steroidogenic enzymes, including steroid sulfatase (STS), hydroxy-delta-5-steroid dehydrogenase 3 betaand steroid delta-isomerase 1 (HSD3B1), 17 $\beta$-hydroxysteroid dehydrogenase type 7 and aromatase (CYP19A1), was investigated in primary tumoral and adjacent healthy gastric mucosa from 60 patients with GC. Furthermore, the mRNA levels for estrogen receptor $\alpha$, estrogen receptor $\beta$ (ESR2) and androgen receptor (AR), along with their coregulators, including proline, glutamate and leucine rich protein 1, CREB binding protein, nuclear receptor coactivator 1 (NCOA1), nuclear receptor corepressor 1 (NCOR1) and nuclear receptor subfamily 2 group F member 1 (NR2F1), were investigated. Additionally, the association between the mRNA expression of these genes and the clinicopathological features of patients with GC was examined. Significantly decreased levels of STS, HSD3B1, ESR2, AR, NCOA1 and NCOR1 mRNA, in addition to significantly increased levels of CYP19A1 mRNA were demonstrated in tumoral tissue samples compared with
\end{abstract}

Correspondence to: Mr. Bartosz Adam Frycz, Department of Biochemistry and Molecular Biology, Poznań University of Medical Sciences, 6 Święcickiego Street, 60-781 Poznań, Poland E-mail: bartekfrycz@gmail.com

Key words: steroidogenesis, steroidogenic enzymes, steroid hormone receptors, steroid hormone receptor co-regulators, gastric cancer adjacent healthy gastric tissue samples. Deregulated expression of these genes in the analyzed tissue samples was associated with certain clinicopathological features of GC, such as age and localization of the tumor. The results of the current study suggest that all of the genes analyzed are expressed in tumoral and adjacent healthy gastric mucosa. In addition, the results indicate that abnormal expression of STS, ESR2, AR, NCOA1 and NCOR1 may serve a role in the development and progression of GC, and may be associated with specific clinicopathological features in patients with GC.

\section{Introduction}

The global incidence and mortality rates of gastric cancer (GC) are amongst the highest for all malignant tumor types (1). Risk factors that may increase an individual's chance of developing GC include Helicobacter pylori infection, a diet high in salty/smoked food and low in fruit/vegetables, tobacco smoking and genetic susceptibility (2). Additionally, the incidence rate of GC is $\sim 2$ times higher in males compared with females, independently of known gender-specific variables (3). Therefore, it has been proposed that steroid hormone production influences the risk of developing GC (4,5). Furthermore, numerous studies have suggested a protective role of $17 \beta$-estradiol (E2) in gastric carcinogenesis (6-12). Although the majority of E2 is produced in the ovaries, it is also synthesized locally in peripheral tissues in males and females (13).

There are two routes involved in the local synthesis of E2, the sulfatase and aromatase signaling pathways (13). The sulfatase signaling pathway involves the desulfation of dehydroepiandrosterone sulfate (DHEA-S) and estrone sulfate (E1-S) to DHEA and E1, respectively, by steroid sulfatase (STS). Subsequently, E1 is reduced to E2 by $17 \beta$-hydroxysteroid dehydrogenases (HSD17Bs; types 1, 5 and 7). In addition, DHEA is converted to androstenedione (adione) by hydroxy-delta-5-steroid dehydrogenase 3 beta- and steroid delta-isomerase 1 (HSD3B1). In the aromatase signaling pathway, adione and testosterone are converted into E1 and E2, respectively, by 
aromatase (CYP19A1) (14). In recent studies, the mRNA and protein expression of enzymes belonging to the HSD17B family, including HSD17B1, 2 and 5 was demonstrated in healthy and tumoral gastric mucosa (15-17). In addition, it was revealed that the HGC-27 and EPG 85-257 GC cell lines were able to synthesize E2 in vitro (15).

In the present study, the mRNA levels of certain genes that participate in the synthesis of E2 through the sulfatase and aromatase signaling pathways, including STS, HSD3B1, CYP19A1 and HSD17B7, were investigated in primary tumoral and healthy adjacent gastric mucosa samples from patients with GC. Furthermore, considering the fact that the cellular functions of steroid hormones are mediated through binding to their receptors and that the abnormal expression of genes encoding nuclear estrogen receptors $\alpha$ (ESR1) and $\beta$ (ESR2), and androgen receptor (AR) have been demonstrated in GC $(18,19)$, the mRNA expression of coactivators and corepressors of steroid hormone receptors were also determined in the tissue samples. The following coactivators and corepressors were investigated: Proline, glutamate and leucine rich protein 1 (PELP1); CREB binding protein (CREBBP); nuclear receptor coactivator 1 (NCOA1); nuclear receptor corepressor 1 (NCOR1); and nuclear receptor subfamily 2 , group F, member 1 (NR2F1). Additionally, the association between the mRNA expression of the genes investigated and the clinicopathological features of patients with $\mathrm{GC}$ was investigated.

\section{Materials and methods}

Patients and tissue specimens. Primary tumoral gastric mucosa specimens were collected between December 2012 and September 2015 from 60 patients with a mean age of 67.2 years old who underwent a total gastrectomy at the First Department of Surgical Oncology and General Surgery at the Greater Poland Cancer Centre or the Department of General and Endocrine Surgery and Gastroenterological Oncology, Heliodor Święcicki Clinical Hospital at the Poznań University of Medical Sciences (Poznań, Poland). The clinicopathological characteristics of the patients are presented in Table I; however, for certain patients not all the information was available. In addition, healthy gastric mucosa tissue samples located $\geq 10 \mathrm{~cm}$ away from the tumoral lesions was obtained from each patient. Specimens were snap-frozen in liquid nitrogen and stored at $-80^{\circ} \mathrm{C}$ until required for RNA isolation. An experienced pathologist performed histopathological assessments of the tissue samples (Table I). The present study was approved by the Ethics Committee of Poznań University of Medical Sciences. Written informed consent was obtained from all patients.

Reverse transcription-quantitative polymerase chain reaction analysis. Total RNA from patient tissue samples was isolated according to Chomczynski and Sacchi's single-step method (20), which involves homogenization. The concentration and integrity of the RNA isolated was assessed using a Nano-100 Micro Spectrophotometer (Hangzhou Allsheng Instruments Co., Ltd., Hangzhou, China) and non-denaturing electrophoresis on a $1.5 \%$ agarose gel, respectively. RNA samples were treated with DNase I and reverse-transcribed into cDNA using a SuperScript ${ }^{\circledR}$ III First-Strand Synthesis system (Thermo Fisher Scientific, Inc., Waltham, MA, USA) according to the manufacturer's protocol, using $1 \mu \mathrm{g}$ of RNA as a template.

The target cDNA was quantified by the relative quantification method using a calibrator, as is described in the Relative Quantification Manual (Roche Diagnostics GmbH, Mannheim, Germany) (21). The calibrator was prepared as a cDNA mix from all of the patient samples and its successive dilutions were used to create a standard curve. qPCR reactions were performed using a LightCycler ${ }^{\circledR} 480$ Real-Time PCR system (Roche Diagnostics GmbH, Mannheim, Germany). Each qPCR reaction contained $1 \mu \mathrm{l}$ of total cDNA solution obtained in reverse transcription, $9 \mu 1$ LightCycler 480 SYBR Green I Master mix (Roche Diagnostics GmbH) and $0.1 \mu \mathrm{M}$ of the corresponding primer pair (Table II). Primers for ESR1, ESR2 and HSD17B7 were purchased from Sigma-Aldrich (Merck Millipore, Darmstadt, Germany) and the $\beta 2$-microglobulin (B2M) primers were previously designed by Hashimoto et al (22). The primers for CYP19A1 were designed using the Universal ProbeLibrary website (Roche Diagnostics $\mathrm{GmbH}$ ). All other primers were designed using OLIGO Primer Analysis Software (version 5.0; Molecular Biology Insights, Inc., Colorado Springs, CO, USA). qPCR thermocycling conditions consisted of a pre-denaturation step at $95^{\circ} \mathrm{C}$ for $7 \mathrm{~min}$ followed by $42 \mathrm{PCR}$ cycles specific for each primer. Reaction conditions for each primer pair are detailed in Table II. The analyzed transcript levels were expressed as the ratio between the amount of target transcript in a sample and target transcript in the calibrator. The quantity of analyzed transcripts in each sample was standardized by the geometric mean of B2M, $\beta$-glucuronidase and porphobilinogen deaminase, and presented as the decimal logarithm.

Statistical analysis. Normality of data distribution was assessed using the Shapiro-Wilk test, followed by a Student's t-test (two-tailed) or Mann-Whitney U test to determine significant differences between mean values. $\mathrm{P}<0.01$ was considered to indicate a statistically significant difference. STATISTICA software (version 10; StatSoft, Inc., Tulsa, OK, USA) was used to perform all statistical analyses.

\section{Results}

mRNA expression of STS, HSD3B1, CYP19A1, HSD17B7, ESR1, ESR2, AR, PELP1, CREBBP, NCOA1, NCOR1 and $N R 2 F 1$ in primary tumoral and healthy gastric mucosa of patients with GC. RT-qPCR was used to measure the mRNA expression of genes encoding steroidogenic enzymes (STS, CYP19A1, HSD3B1, HSD17B7), steroid hormone receptors (ESR1, ESR2, AR) and coregulators of steroid hormone receptors (PELP1, CREBBP, NCOA1, NCOR1, NR2F1), in primary tumoral and adjacent healthy mucosa tissue samples from 60 patients with GC (Fig. 1). Expression of STS and HSD17B7 mRNA was detected in all tissue samples examined, whereas expression of HSD3B1 mRNA was absent in one healthy tissue sample and CYP19A1 was not detected in seven healthy specimens (Fig. 1A). Furthermore, five cancerous tissue samples demonstrated no expression of HSD3B1 mRNA. There was no difference in the mRNA level of HSD17B7 in primary tumoral and adjacent healthy mucosa $(\mathrm{P}=0.2$; Fig. $1 \mathrm{~A})$. However, 
Table I. Available clinicopathological characteristics of patients with gastric cancer.

\begin{tabular}{|c|c|}
\hline Clinicopathological characteristic & No. of patients \\
\hline Gender (male/female) & $36 / 24$ \\
\hline \multicolumn{2}{|l|}{ GC localization } \\
\hline Multisite & 31 \\
\hline Cardia & 10 \\
\hline Trunk & 6 \\
\hline Fundus & 1 \\
\hline Lesser curvature & 5 \\
\hline Pylorus & 3 \\
\hline \multicolumn{2}{|l|}{ Histological type } \\
\hline Diffuse & 19 \\
\hline Intestinal & 23 \\
\hline Undetermined & 12 \\
\hline \multicolumn{2}{|l|}{ Tumor stage } \\
\hline $\mathrm{T} 1$ & 2 \\
\hline $\mathrm{T} 2$ & 9 \\
\hline $\mathrm{T} 3$ & 32 \\
\hline $\mathrm{T} 4$ & 15 \\
\hline \multicolumn{2}{|l|}{ Lymph node metastasis stage } \\
\hline No & 17 \\
\hline N1 & 8 \\
\hline $\mathrm{N} 2$ & 14 \\
\hline N3 & 19 \\
\hline \multicolumn{2}{|l|}{ Metastasis stage } \\
\hline M0 & 45 \\
\hline M1 & 3 \\
\hline \multicolumn{2}{|l|}{ Histological grading } \\
\hline G1 & 1 \\
\hline $\mathrm{G} 2$ & 17 \\
\hline G3 & 38 \\
\hline
\end{tabular}

T, tumor; N, node; $M$, metastasis, $G$, grade.

significantly lower mRNA levels of STS $(\mathrm{P}<0.00001)$ and HSD3B1 ( $\mathrm{P}=0.0051)$ were identified in tumoral tissue samples compared with healthy tissue samples. Tumoral tissue samples revealed a significantly increased expression of CYP19A1 mRNA compared with control samples ( $\mathrm{P}<0.00001$; Fig. 1A). However, despite the significant differences observed, HSD3B1 and CYP19A1 mRNA levels were maintained at low levels in primary tumoral and healthy gastric mucosa compared with STS and HSD17B7 mRNA (data not shown).

mRNA of the investigated steroid hormone receptors (Fig. 1B) and their coregulators (Fig. 1C) was detected in all 60 pairs of gastric tumor and adjacent healthy control samples. No significant difference was observed in the expression of ESR1 mRNA between primary tumoral and adjacent healthy mucosa $(\mathrm{P}=0.26$; Fig. 1B). Furthermore, significantly decreased levels of ESR2 $(\mathrm{P}=0.0097)$ and AR $(\mathrm{P}=0.00029)$ mRNA were detected in GC specimens compared with adjacent healthy controls (Fig. 1B). Amongst the steroid hormone receptors investigated, the expression levels of ESR2 and AR mRNA were the highest, with expression of ESR1 mRNA low in tumoral and adjacent healthy gastric tissue samples (data not shown). Amongst the coregulators of steroid hormones receptors examined, the expression of NCOA1 $(\mathrm{P}=0.00021)$ and NCOR1 $(\mathrm{P}=0.00017)$ mRNA was significantly reduced in tumoral mucosa compared with adjacent healthy mucosa (Fig. 1C). In addition, no significant differences were observed in the expression of PELP1 $(\mathrm{P}=0.19), \operatorname{CREBBP}(\mathrm{P}=0.06)$ and NR2F1 $(\mathrm{P}=0.11)$ mRNA between tumoral and healthy tissue samples (Fig. 1C).

Analysis of the clinicopathological characteristics of patients with GC and mRNA levels of STS, HSD3B1, CYP19, ESR2, AR, NCOA1 and NCOR1. Decreased expression of STS, HSD3B1, ESR2, AR, NCOA1 and NCOR1 mRNA, and increased expression of CYP19A1 mRNA in tumoral tissue samples compared with healthy controls, were associated with certain clinicopathological features of patients with GC (Table III). Expression of STS ( $\mathrm{P}<0.00001)$, ESR2 $(\mathrm{P}=0.0024)$, AR $(\mathrm{P}=0.0001)$, NCOA1 $(\mathrm{P}=0.00028)$ and NCOR1 $(\mathrm{P}=0.00067) \mathrm{mRNA}$ were significantly lower in tumoral tissue samples compared with the control in patients $>60$ years. Furthermore, males had significantly lower levels of AR $(\mathrm{P}=0.0018)$, NCOA1 $(\mathrm{P}=0.00051)$ and NCOR1 $(\mathrm{P}=0.000095) \mathrm{mRNA}$ in tumoral tissue samples compared with control tissue samples, whereas in females the mRNA level of HSD3B1 was significantly lower in tumoral compared with control tissue samples $(\mathrm{P}=0.004)$.

The multisite localization of GC was demonstrated to be associated with a significantly lower level of HSD3B1 mRNA $(\mathrm{P}=0.0034)$ and tumors located in the cardia region had significantly lower STS $(\mathrm{P}=0.0012), \mathrm{AR}(\mathrm{P}=0.0012)$, NCOA1 $(\mathrm{P}=0.001)$ and NCOR1 $(\mathrm{P}=0.0073) \mathrm{mRNA}$, compared with healthy mucosa. However, only 10 patients with tumor localization in the cardia region were included in the analysis. Patients with the intestinal type of GC had significantly lower mRNA levels of AR $(\mathrm{P}=0.000046)$ and NCOA1 $(\mathrm{P}=0.0007)$ in tumoral tissue samples compared with the control mucosa. In addition, significantly lower levels of STS mRNA were identified in tumoral tissue compared with adjacent healthy tissue in patients with indeterminate GC $(\mathrm{P}=0.0032)$. Additionally, cancerous tissue samples of a T3 grade expressed significantly lower levels of STS $(\mathrm{P}=0.00018)$ and HSD3B1 $(\mathrm{P}=0.0062)$ mRNA compared with healthy tissue samples. A significantly lower level of AR mRNA was also identified in tumoral tissue graded as T4 compared with the control $(\mathrm{P}=0.0086)$. Expression of STS mRNA was significantly decreased in the tumoral tissue samples of patients with N3 lymph node metastases compared with the controls samples $(\mathrm{P}=0.000089)$.

The majority of patients were diagnosed with an M0 metastasis stage, thus no associations between the mRNA levels of the analyzed genes and metastasis grade were investigated. Significantly lower levels of AR $(\mathrm{P}=0.00062)$ and NCOA1 $(\mathrm{P}=0.0027)$ mRNA were identified in the tumoral tissue of patients with G2 stage GC compared with adjacent healthy tissue. In addition, STS $(\mathrm{P}=0.000054)$ and HSD3B1 $(\mathrm{P}=0.0012) \mathrm{mRNA}$ expression was significantly lower in G3 histological grade tumors compared with healthy tissue 
Table II. Primer sequences and qPCR conditions.

\begin{tabular}{|c|c|c|c|c|}
\hline Gene & Sequence $\left(5^{\prime}-3^{\prime}\right)$ & Exon number & $\begin{array}{l}\text { Product } \\
\text { size (bp) }\end{array}$ & $\begin{array}{l}\text { qPCR thermocycling } \\
\text { conditions (denaturation; } \\
\text { annealing; elongation) }\end{array}$ \\
\hline STS & $\begin{array}{l}\text { GCCAGAAGATTGATGAGCCCAC } \\
\text { AGGCGTTGCAGTAATGGAAGAG }\end{array}$ & $\begin{array}{l}\text { ENSE00001203198 } \\
\text { ENSE00001136339 }\end{array}$ & 174 & $\begin{array}{l}95^{\circ} \mathrm{C} / 8 \mathrm{sec} \\
62^{\circ} \mathrm{C} / 8 \mathrm{sec} \\
72^{\circ} \mathrm{C} / 8 \mathrm{sec}\end{array}$ \\
\hline HSD3B1 & $\begin{array}{l}\text { GATGTCTTCGGTGTCACTCA } \\
\text { GGCTACCTCTATGCTACTG }\end{array}$ & $\begin{array}{l}\text { ENSE00001722296 } \\
\text { ENSE00001846945 }\end{array}$ & 129 & $\begin{array}{l}95^{\circ} \mathrm{C} / 8 \mathrm{sec} \\
57^{\circ} \mathrm{C} / 8 \mathrm{sec} \\
72^{\circ} \mathrm{C} / 8 \mathrm{sec}\end{array}$ \\
\hline CYP19A1 & $\begin{array}{l}\text { CAAACCCAATGAATTTACTCT } \\
\text { ACCATGGCGATGTACTTTCC }\end{array}$ & $\begin{array}{l}\text { ENSE00003683464 } \\
\text { ENSE00001524808 }\end{array}$ & 111 & $\begin{array}{l}95^{\circ} \mathrm{C} / 6 \mathrm{sec} \\
58^{\circ} \mathrm{C} / 6 \mathrm{sec} \\
72^{\circ} \mathrm{C} / 6 \mathrm{sec}\end{array}$ \\
\hline $\mathrm{AR}$ & $\begin{array}{l}\text { GATCCTTCACCAATGTCAACT } \\
\text { CTCATTCGGACACACTGGCT }\end{array}$ & $\begin{array}{l}\text { ENSE00001282597 } \\
\text { ENSE00001165458 }\end{array}$ & 109 & $\begin{array}{l}95^{\circ} \mathrm{C} / 10 \mathrm{sec} \\
60^{\circ} \mathrm{C} / 10 \mathrm{sec} \\
72^{\circ} \mathrm{C} / 10 \mathrm{sec}\end{array}$ \\
\hline PELP1 & $\begin{array}{l}\text { GAGCATTCAGCAGGTGTTAC } \\
\text { AGGTGGTTCATGGAGATGTC }\end{array}$ & $\begin{array}{l}\text { ENSE00003644127 } \\
\text { ENSE00003476735 }\end{array}$ & 132 & $\begin{array}{l}95^{\circ} \mathrm{C} / 10 \mathrm{sec} \\
60^{\circ} \mathrm{C} / 10 \mathrm{sec} \\
72^{\circ} \mathrm{C} / 10 \mathrm{sec}\end{array}$ \\
\hline CREBBP & $\begin{array}{l}\text { TCTTCCATTGCCACCCACCT } \\
\text { CTGTCTTCAGTTGCTTGTTTG }\end{array}$ & $\begin{array}{l}\text { ENSE00003665970 } \\
\text { ENSE00003538086 }\end{array}$ & 142 & $\begin{array}{l}95^{\circ} \mathrm{C} / 10 \mathrm{sec} \\
60^{\circ} \mathrm{C} / 10 \mathrm{sec} \\
72^{\circ} \mathrm{C} / 10 \mathrm{sec}\end{array}$ \\
\hline NCOA1 & $\begin{array}{l}\text { GCTGGTATCCTTCCTTAGTG } \\
\text { TGGCGTTGCTTGTTGTGGTG }\end{array}$ & $\begin{array}{l}\text { ENSE00000808889 } \\
\text { ENSE00000808890 }\end{array}$ & 136 & $\begin{array}{l}95^{\circ} \mathrm{C} / 10 \mathrm{sec} \\
60^{\circ} \mathrm{C} / 10 \mathrm{sec} \\
72^{\circ} \mathrm{C} / 10 \mathrm{sec}\end{array}$ \\
\hline NCOR1 & $\begin{array}{l}\text { GCGTTATGATCAGCTCATGG } \\
\text { ACTCCTAGCAATGGTGGCTG }\end{array}$ & $\begin{array}{l}\text { ENSE00003681554 } \\
\text { ENSE00003668751 }\end{array}$ & 202 & $\begin{array}{l}95^{\circ} \mathrm{C} / 10 \mathrm{sec} \\
62^{\circ} \mathrm{C} / 10 \mathrm{sec} \\
72^{\circ} \mathrm{C} / 10 \mathrm{sec}\end{array}$ \\
\hline NR2F1 & $\begin{array}{l}\text { CGCATCTTCCAGGAGCAGGT } \\
\text { GCAGTCGCAGCAGCAGTTTG }\end{array}$ & $\begin{array}{l}\text { ENSE00001249995 } \\
\text { ENSE00001250004 }\end{array}$ & 226 & $\begin{array}{l}95^{\circ} \mathrm{C} / 6 \mathrm{sec} \\
60^{\circ} \mathrm{C} / 6 \mathrm{sec} \\
72^{\circ} \mathrm{C} / 6 \mathrm{sec}\end{array}$ \\
\hline GUSB & $\begin{array}{l}\text { CGCCGACTTCTCTGACAAC } \\
\text { ATCACCTCCCGTTCGTACC }\end{array}$ & $\begin{array}{l}\text { ENSE00001799401 } \\
\text { ENSE00003687473 }\end{array}$ & 174 & $\begin{array}{l}95^{\circ} \mathrm{C} / 10 \mathrm{sec} \\
60^{\circ} \mathrm{C} / 10 \mathrm{sec} \\
72^{\circ} \mathrm{C} / 10 \mathrm{sec}\end{array}$ \\
\hline PBGD & $\begin{array}{l}\text { GCCAAGGACCAGGACATC } \\
\text { TCAGGTACAGTTGCCCATC }\end{array}$ & $\begin{array}{l}\text { ENSE00003460195 } \\
\text { ENSE00003609229/ } \\
\text { ENSE00003610664 }\end{array}$ & 160 & $\begin{array}{l}95^{\circ} \mathrm{C} / 10 \mathrm{sec} \\
60^{\circ} \mathrm{C} / 10 \mathrm{sec} \\
72^{\circ} \mathrm{C} / 10 \mathrm{sec}\end{array}$ \\
\hline $\mathrm{B} 2 \mathrm{M}$ & $\begin{array}{l}\text { CACCCCCACTGAAAAAGATG } \\
\text { CCTCCATGATGCTGCTTACA }\end{array}$ & $\begin{array}{l}\text { ENSE00003659794 } \\
\text { ENSE00003459883/ } \\
\text { ENSE00002538889 }\end{array}$ & 106 & $\begin{array}{l}95^{\circ} \mathrm{C} / 10 \mathrm{sec} \\
60^{\circ} \mathrm{C} / 10 \mathrm{sec} \\
72^{\circ} \mathrm{C} / 10 \mathrm{sec}\end{array}$ \\
\hline
\end{tabular}

qPCR, quantitative polymerase chain reaction; STS, steroid sulfatase; HSD3B1, hydroxy-delta-5-steroid dehydrogenase 3 beta- and steroid delta-isomerase 1; CYP19A1, aromatase; AR, androgen receptor; PELP1, proline, glutamate and leucine rich protein 1; CREBBP, CREB binding protein; NCOA1, nuclear receptor coactivator 1; NCOR1, nuclear receptor corepressor 1; NR2F1, nuclear receptor subfamily 2 , group F, member 1; GUSB, $\beta$-glucuronidase; PBGD, porphobilinogen deaminase; B2M, $\beta 2$-microglobulin.

samples. However, the expression of CYP19A1 mRNA was significantly increased in tumoral tissue samples compared with the control in patients with multisite localization of GC $(\mathrm{P}=0.00001)$, a T3 tumor stage $(\mathrm{P}=0.00001), \mathrm{N} 0(\mathrm{P}=0.0024)$ or $\mathrm{N} 3(\mathrm{P}=0.001)$ lymph node metastasis grades and $\mathrm{G} 3$ histological grade tumors $(\mathrm{P}<0.00001)$. The expression of CYP19A1 mRNA in primary tumoral tissue samples compared with healthy adjacent mucosa samples was significantly increased in all patients studied, regardless of age, gender, and histological type and localization of the tumor.

\section{Discussion}

In the present study, the mRNA levels of specific genes involved in the synthesis of E2, in addition to genes encoding steroid hormone receptors and their coregulators, were investigated in primary tumoral and adjacent healthy gastric mucosa samples obtained from patients with GC. The presence of mRNA was detected for all genes analyzed in the majority of gastric specimens examined. Furthermore, it was identified that the expression of STS, HSD3B1, ESR2, AR, NCOA1 and 
A

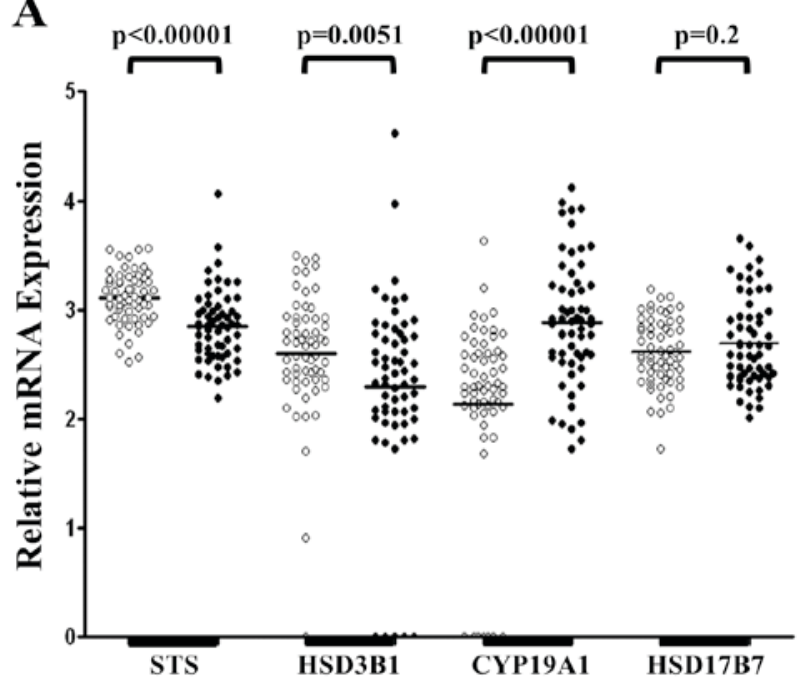

B

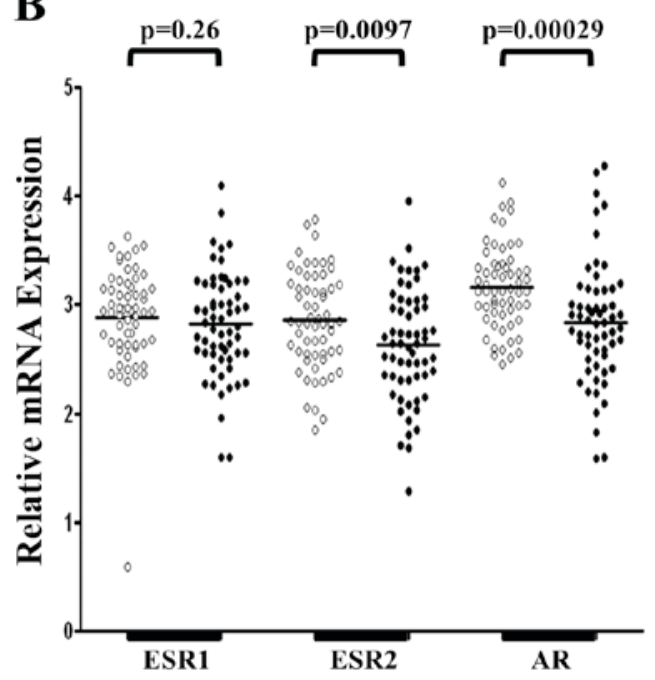

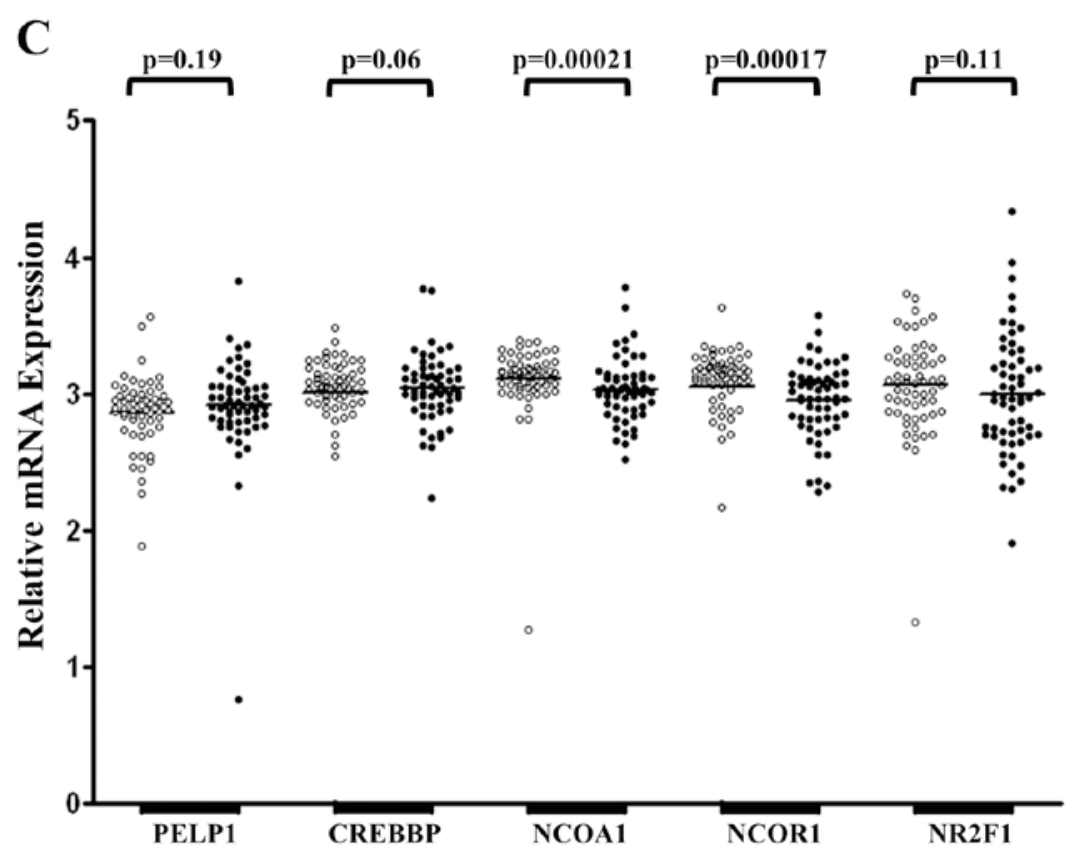

Figure 1. Relative expression of STS, HSD3B1, CYP19A1, HSD17B7, ESR1, ESR2, AR, PELP1, CREBBP, NCOA1, NCOR1 and NR2F1 mRNA in healthy and primary tumoral gastric tissue samples. (A) Expression of genes encoding steroidogenic enzymes. (B) Expression levels of genes encoding steroid hormone receptors. (C) Expression of genes encoding coregulators of steroid hormone receptors. White dots represent healthy tissue and black dots represent primary tumoral tissue from patients with gastric cancer, which were analyzed through reverse transcription-quantitative polymerase chain reaction analysis and normalized to expression levels of $\beta 2$-microglobulin, $\beta$-glucuronidase and porphobilinogen deaminase. The quantity of analyzed genes is presented as the decimal logarithm that represents the ratio between the amount of target gene in a sample and the target gene in the calibrator. STS, steroid sulfatase; HSD3B1, hydroxy-delta-5-steroid dehydrogenase 3 beta- and steroid delta-isomerase 1; CYP19A1, aromatase; HSD17B7, 17 $\beta$-hydroxysteroid dehydrogenase type 7; ESR1, estrogen receptor $\alpha$; ESR2, estrogen receptor $\beta$; AR, androgen receptor; PELP1, proline, glutamate and leucine rich protein 1; CREBBP, CREB binding protein; NCOA1, nuclear receptor coactivator 1; NCOR1, nuclear receptor corepressor 1; NR2F1, nuclear receptor subfamily 2, group F, member 1 .

NCOR1 mRNA was significantly decreased, whereas, the level of CYP19A1 mRNA was significantly increased, in cancerous gastric tissue compared with the control samples. To the best of our knowledge, no previous studies have investigated the expression of STS, HSD3B1 and NCOA1 mRNA in patients with GC, although their association with other tumor types has been examined.

Previous studies have identified lower levels of STS mRNA in primary colorectal adenocarcinoma compared with adjacent healthy colon mucosa (23). This is consistent with the results of the present study, which identified significantly decreased levels of STS mRNA in tumoral compared with healthy gastric tissue. As E1 and DHEA are typically found in their inactive sulfated form in the blood and have to undergo STS-mediated activation prior to entering the steroidogenesis pathway $(24,25)$, downregulation of STS in a particular tissue may suppress the synthesis of estrogens and androgens (26). By contrast, higher levels of E2 have been identified in cancerous tissue compared with healthy tissue in patients with breast cancer $(26,27)$. In addition, numerous studies have reported 
Table III. Association between the expression of STS, HSD3B1, CYP19, ESR2, AR, NCOA1 and NCOR1 mRNA in tumoral and healthy gastric tissue samples and the clinicopathological characteristics of patients with GC.

\begin{tabular}{|c|c|c|c|c|c|c|c|}
\hline \multirow{2}{*}{$\begin{array}{l}\text { Clinicopathological } \\
\text { characteristic }\end{array}$} & \multicolumn{7}{|c|}{ Gene analyzed (P-value, GC vs. control tissue) } \\
\hline & $\downarrow \mathrm{STS}^{\mathrm{a}}$ & $\downarrow H S D 3 B 1^{b}$ & $\uparrow C Y P 19 A 1^{\mathrm{b}}$ & $\downarrow \mathrm{ESR} 2^{\mathrm{a}}$ & $\downarrow \mathrm{AR}^{\mathrm{a}}$ & $\downarrow N C O A 1^{\mathrm{b}}$ & $\downarrow \mathrm{NCOR} 1^{\mathrm{b}}$ \\
\hline All patients & $<0.00001$ & 0.0051 & $<0.00001$ & 0.0097 & 0.00029 & 0.00021 & 0.00017 \\
\hline \multicolumn{8}{|l|}{ Age (years old) } \\
\hline$\leq 60$ & 0.9 & 0.2 & 0.00074 & 0.89 & 0.35 & 0.27 & 0.22 \\
\hline$>60$ & $<0.00001$ & 0.02 & 0.000012 & 0.0024 & 0.0001 & 0.00028 & 0.00067 \\
\hline \multicolumn{8}{|l|}{ Gender } \\
\hline Male & 0.0014 & 0.28 & 0.000072 & 0.08 & 0.0018 & 0.00051 & 0.000095 \\
\hline Female & 0.000069 & 0.004 & 0.00023 & 0.056 & 0.04 & 0.11 & 0.48 \\
\hline \multicolumn{8}{|l|}{ GC localization } \\
\hline Multisite & 0.013 & 0.0034 & 0.00001 & 0.04 & 0.026 & 0.12 & 0.11 \\
\hline Cardia & 0.0012 & 0.57 & 0.054 & 0.55 & 0.0012 & 0.001 & 0.0073 \\
\hline Body & - & - & - & - & - & - & - \\
\hline Fundus & - & - & - & - & - & - & - \\
\hline Lesser curvature & - & - & - & - & - & - & - \\
\hline Pylorus & - & - & - & - & - & - & - \\
\hline \multicolumn{8}{|l|}{ Histological type } \\
\hline Diffuse & 0.034 & 0.034 & 0.0018 & 0.73 & 0.69 & 0.36 & 0.038 \\
\hline Intestinal & 0.037 & 0.022 & 0.0074 & 0.022 & 0.000046 & 0.0007 & 0.019 \\
\hline Indeterminate & 0.0032 & 0.14 & 0.0009 & 0.047 & 0.47 & 0.71 & 0.98 \\
\hline \multicolumn{8}{|l|}{ Tumor stage } \\
\hline $\mathrm{T} 1$ & - & - & - & - & - & - & - \\
\hline $\mathrm{T} 2$ & 0.57 & 0.96 & 0.11 & 0.79 & 0.19 & 0.093 & 0.077 \\
\hline $\mathrm{T} 3$ & 0.00018 & 0.0062 & 0.00001 & 0.022 & 0.027 & 0.016 & 0.038 \\
\hline $\mathrm{T} 4$ & 0.014 & 0.11 & 0.089 & 0.14 & 0.0086 & 0.046 & 0.074 \\
\hline \multicolumn{8}{|c|}{ Lymph node metastasis stage } \\
\hline No & 0.17 & 0.11 & 0.0024 & 0.29 & 0.16 & 0.039 & 0.027 \\
\hline N1 & 0.18 & 0.27 & 0.052 & 0.76 & 0.035 & 0.014 & 0.024 \\
\hline $\mathrm{N} 2$ & 0.019 & 0.49 & 0.041 & 0.22 & 0.38 & 0.48 & 0.53 \\
\hline N3 & 0.000089 & 0.06 & 0.001 & 0.045 & 0.048 & 0.062 & 0.21 \\
\hline \multicolumn{8}{|l|}{ Metastasis stage } \\
\hline M0 & 0.0021 & 0.003 & $<0.00001$ & 0.014 & 0.00064 & 0.0028 & 0.0018 \\
\hline M1 & - & - & - & - & - & - & - \\
\hline \multicolumn{8}{|l|}{ Histological grading } \\
\hline G1 & - & - & - & - & - & - & - \\
\hline G2 & 0.07 & 0.07 & 0.036 & 0.24 & 0.00062 & 0.0027 & 0.042 \\
\hline G3 & 0.000054 & 0.0012 & $<0.00001$ & 0.027 & 0.044 & 0.021 & 0.0049 \\
\hline
\end{tabular}

an increase in the activity and expression of STS in breast cancer (28-33). Therefore, it has been suggested that upregulation of STS may be associated with higher concentrations of intratumoral E2 $(28,30,32)$.

Desulfated DHEA that is converted into adione, typically by HSD3B1, may serve as a substrate of E2 synthesis through the aromatase signaling pathway (25). However, low expression of HSD3B1 mRNA was observed in tumoral and healthy gastric tissue samples, with expression lower in the tumoral mucosa compared with the adjacent healthy tissue. Conversely to the results of the present study, increased expression of HSD3B1 mRNA has been identified in benign prostatic 
hyperplasia compared with healthy adjacent prostate tissue samples (34), in addition to castration-resistant metastases compared with primary prostate tumors (35). HSD3B1 activity is essential for the production of adione, which is subsequently used as a substrate for the synthesis of testosterone, an important hormone that regulates the proliferation of prostate cells (36). Furthermore, adione and testosterone can be directly converted to E1 and E2, respectively, by CYP19A1 (25). In the current study, expression of CYP19A1 mRNA was demonstrated in the majority of healthy gastric tissue samples and all tumoral gastric tissue samples. A previous study identified the presence of CYP19A1 in 23/30 GC tissue samples; however, all healthy gastric mucosa specimens tested negative for this enzyme (37). The presence of CYP19A1 mRNA and protein has been revealed in healthy and tumoral gastric tissue samples, although no significant difference in the level of CYP19A1 mRNA was demonstrated between healthy and tumoral gastric tissue samples (38). These findings oppose the results of the present study; however, this may have been due to the fact that the previous study analyzed a total of five cases (38).

Numerous animal studies have demonstrated that parietal cells are capable of converting circulating androgens into estrogens, whilst simultaneously expressing CYP19A1 (39-44). Furthermore, the synthesis of E2 through the aromatization of exogenous testosterone has been demonstrated in various GC cell lines (38). Considering these findings and the numerous evidence for the protective role of E2 against GC (6-12), the increased level of CYP19A1 mRNA in tumoral tissue samples compared with the control group observed in the present study is difficult to explain. However, it was observed that the expression of CYP19A1 mRNA in cancerous and healthy tissues was maintained at a low level, indicating that the role CYP19A1 serves in estrogen synthesis in gastric tissue may be limited. Additionally, it has been demonstrated that E2 may inhibit CYP19A1 and STS activity in breast cancer cells $(45,46)$, suggesting that the increased mRNA expression of CYP19A1 in GC could be due to lower intracellular concentrations of E2.

Cellular responses to steroid hormones are facilitated by steroid hormones binding to their receptors, such as ESR1, ESR2 and AR (47). Studies that investigated the association between these receptors and GC have produced inconsistent results $(18,19,48)$. ESR1 has been suggested to mediate the cancer-promoting effects of E2 in breast $(49,50)$, colon (51), prostate (52) and gastric (53-57) cells, whereas binding of E2 to ESR2 could inhibit cell proliferation in tumors of these tissues $(51,53,55,57-61)$. In the current study, no significant difference in the expression of ESR1 mRNA was identified between healthy and tumoral gastric tissue samples; however, the expression of ESR2 mRNA was significantly lower in cancerous mucosa compared with the control. Thus, the results of the present study support the hypothesis that reduced ESR2 expression is associated with the development of GC. Conversely, Matsuyama et al (62) suggested that the role served by ESR2 in GC may differ depending on the subtype. Furthermore, Guo et al (63) demonstrated that certain splicing variants of ESR2 mRNA (ESR2-1, -2 and -5) are differentially expressed in GC and healthy tissue samples. Additionally, higher levels of ESR2-5 mRNA were detected in GC compared with healthy tissue samples, and were associated with tumor-node-metastasis (TNM) staging, while decreased mRNA levels of ESR2-1 in GC did not correlate with any clinicopathological characteristics. In the current study, patients who were $>60$ years old had significantly lower levels of ESR2 mRNA in tumoral compared with healthy gastric tissue samples; however, all ESR2 splicing variants were analyzed simultaneously. A previous study suggested that ESR1 may exhibit antiproliferative activity, and reduce the motility and invasion of GC cells (64). Furthermore, ESR1 has been associated with an early TNM stage in GC (18). Thus, further studies investigating the role of ESRs in the etiology of GC are warranted.

In addition to investigating ESRs, the expression of AR mRNA was investigated in the current study. Previous studies have proposed that AR expression is an unfavorable factor in GC $(19,65,66)$. In the present study, it was demonstrated that expression of AR mRNA was significantly decreased in GC tissue compared with controls. Similarly, decreased mRNA expression of AR in GC tissue samples has been reported by Gan et al (18). Low expression of AR and ESR1 mRNA was observed in cancerous and wild-type gastric mucosa, whereas the ESR2 mRNA was predominantly expressed in the both of these tissues. However, the expression of AR and ESR2 mRNA in GC tissue samples and matched controls was the highest amongst the analyzed steroid hormone receptors in the present study. The STS substrates E1-S and DHEA-S have been demonstrated to induce transactivation of ESRs and AR in a concentration-dependent manner in the MVLN invasive ductal carcinoma and CHO-K1 ovarian cell lines, respectively (67). The results of the current study suggest that DHEA-S is hydrolyzed by STS prior to AR activation, whereas E1-S may be active prior to STS-mediated hydrolysis. Thus, the decreased expression of AR mRNA in GC may have been due to reduced androgen synthesis caused by STS downregulation. Notably, decreased expression of HSD3B1 mRNA, which is essential for androgen synthesis from DHEA, was detected in the present study.

The activity of nuclear steroid hormone receptors is regulated by various coactivators and corepressors (68). In the current study, NCOR1 and NCOA1 were demonstrated to be downregulated in GC tissue samples compared with healthy controls. Furthermore, mRNA and protein expression of NCOR1 has been identified to be downregulated in gastrointestinal stromal tumors, where it has been proposed to serve as a tumor suppressor through the SMAD signaling pathway (69). In contrast to these findings, another study identified increased mRNA expression of NCOR1 in malignant endometrial tissue samples compared with healthy tissue samples (70). Furthermore, high mRNA expression of NCOR1 has been associated with the improved prognosis of patients with breast cancer (71), whereas a loss of nuclear NCOR1 has been revealed to cause increased expression of cancer-associated genes and be significantly associated with the progression of invasive malignant melanoma (72). Upregulation of NCOR1 mRNA and protein expression, induced by progestins, has been associated with the suppression of estrogen-induced growth in T47D breast cancer cells (73).

In the present study, it was demonstrated that expression of NCOA1 mRNA was reduced in tumoral compared with healthy gastric tissue samples. Similarly, downregulation 
of NCOA1 mRNA has been identified in cancerous bladder urothelium samples (74). Additionally, high mRNA levels of NCOA1 have been observed in healthy breast tissue samples, intermediate levels in tumoral tissue samples and low levels in breast cancer cell lines (75). However, numerous studies have identified an association between increased expression of NCOA1 and enhanced angiogenesis, cell proliferation and survival, disease recurrence, higher tumor grade and poor prognosis in breast cancer (76-81). Notably, upregulation of NCOA1 has been observed in patients with breast cancer treated with aromatase inhibitors (82). Thus, the decreased levels of NCOA1 mRNA in GC tissue identified in the present study may have been due to upregulation of CYP19A1 mRNA in tumoral gastric mucosa. Tai et al (83) demonstrated that overexpression of NCOA1 enhanced the E2-induced growth of MCF-7 breast cancer cells. Increased expression of NCOA1 has also been associated with the DHEA-mediated activation of AR in prostate cancer (84). Therefore, the decreased expression of AR and NCOA1 mRNA that were observed in cancerous gastric tissue samples in the present study may have been the result of limited desulfation of DHEA-S due to the downregulation of STS.

In conclusion, the presence of STS, HSD3B1, CYP19A1, HSD17B7, ESR1, ESR2, AR, PELP1, CREBBP, NCOA1, NCOR1 and NR2F1 mRNA was demonstrated in the majority of tumoral and adjacent healthy gastric mucosa tissue samples. Furthermore, significantly decreased mRNA levels of STS and HSD3B1, in addition to significantly increased expression levels of CYP19A1 mRNA, in tumoral gastric tissue samples compared with matched controls were identified. However, compared with STS, the expression of HSD3B1 and CYP19A1 mRNA was low in the majority of the examined tissue samples, indicating that their role in gastric carcinogenesis is limited. Additionally, tumoral gastric tissue samples exhibited decreased levels of NCOA1 and NCOR1 mRNA compared with adjacent healthy controls, suggesting that deregulated expression of these coregulators may serve a role in gastric carcinogenesis. A limitation of the current study was the use of homogenized tissue samples, and thus the possibility that the samples included non-cancerous cells, such as fibroblasts, endothelial cells, smooth muscle cells or blood cells, could not be excluded. Furthermore, mRNA abundance does not always correlate with protein expression. Therefore, further studies on the expression levels of the genes involved in the steroidogenesis pathway and their role in gastric carcinogenesis are warranted.

\section{Acknowledgements}

The present study was supported by the Poznań University of Medical Sciences (grant nos. 502-14-01124182-09811 and 502-01-01118170-05274).

\section{References}

1. Jemal A, Bray F, Center MM, Ferlay J, Ward E and Forman D: Global cancer statistics. CA Cancer J Clin 61: 69-90, 2011.

2. Karimi P, Islami F, Anandasabapathy S, Freedman ND and Kamangar F: Gastric cancer: Descriptive epidemiology, risk factors, screening and prevention. Cancer Epidemiol Biomarkers Prev 23: 700-713, 2014.
3. Sipponen P and Correa P: Delayed rise in incidence of gastric cancer in females results in unique sex ratio $(\mathrm{M} / \mathrm{F})$ pattern: Etiologic hypothesis. Gastric Cancer 5: 213-219, 2002.

4. Hogan AM, Collins D, Baird AW and Winter DC: Estrogen and gastrointestinal malignancy. Mol Cell Endocrinol 307: 19-24, 2009.

5. Camargo MC, Goto Y, Zabaleta J, Morgan DR, Correa P and Rabkin CS: Sex hormones, hormonal interventions, and gastric cancer risk: A meta-analysis. Cancer Epidemiol Biomarkers Prev 21: 20-38, 2012.

6. Lindblad M, Ye W, Rubio C and Lagergren J: Estrogen and risk of gastric cancer: A protective effect in a nationwide cohort study of patients with prostate cancer in Sweden. Cancer Epidemiol Biomarkers Prev 13: 2203-2207, 2004

7. Nylander-Koski O, Kiviluoto T, Puolakkainen P, Kivilaakso E and Mustonen $\mathrm{H}$ : The effect of nitric oxide, growth factors, and estrogen on gastric cell migration. J Surg Res 143: 230-237, 2007.

8. Ohtani M, García A, Rogers AB, Ge Z, Taylor NS, Xu S, Watanabe K, Marini RP, Whary MT, Wang TC and Fox JG: Protective role of 17 beta-estradiol against the development of Helicobacter pylori-induced gastric cancer in INS-GAS mice. Carcinogenesis 28: 2597-2604, 2007.

9. Chandanos E and Lagergren J: Oestrogen and the enigmatic male predominance of gastric cancer. Eur J Cancer 44: 2397-2403, 2008.

10. Duell EJ, Travier N, Lujan-Barroso L, Boutron-Ruault MC, Clavel-Chapelon F, Palli D, Krogh V, Mattiello A, Tumino R, Sacerdote C, et al: Menstrual and reproductive factors, exogenous hormone, use and gastric cancer risk in a cohort of women from the European Prospective Investigation Into Cancer and Nutrition. Am J Epidemiol 172: 1384-1393, 2010.

11. Ohtani M, Ge Z, García A, Rogers AB, Muthupalani S, Taylor NS, Xu S, Watanabe K, Feng Y, Marini RP, et al: $17 \beta$-estradiol suppresses Helicobacter pylori-induced gastric pathology in male hypergastrinemic INS-GAS mice. Carcinogenesis 32: 1244-1250, 2011

12. Sheh A, Ge Z, Parry NM, Muthupalani S, Rager JE, Raczynski AR, Mobley MW, McCabe AF, Fry RC, Wang TC and Fox JG: $17 \beta$-estradiol and tamoxifen prevent gastric cancer by modulating leukocyte recruitment and oncogenic pathways in Helicobacter pylori-infected INS-GAS male mice. Cancer Prev Res (Phila) 4: 1426-1435, 2011.

13. Simpson ER: Sources of estrogen and their importance. J Steroid Biochem Mol Biol 86: 225-230, 2003.

14. Labrie F: All sex steroids are made intracellularly in peripheral tissue by the mechanisms of intracrinology after menopause. J Steroid Biochem Mol Biol 145: 133-138, 2015.

15. Frycz BA, Murawa D, Wysocki-Borejsza M, Marciniak R, Murawa P, Drews M and Jagodziński PP: Expression of $17 \beta$-hydroxysteroid dehydrogenase type 1 in gastric cancer. Biomed Pharmacother 67: 651-657, 2013.

16. Frycz BA, Murawa D, Borejsza-Wysocki M, Marciniak R, Murawa P, Drews M and Jagodziński PP: Expression of $17 \beta$-hydroxysteroid dehydrogenase type 2 is associated with some clinicopathological features in gastric cancer. Biomed Pharmacother 70: 24-27, 2015.

17. Frycz BA, Murawa D, Borejsza-Wysocki M, Wichtowski M, Spychała A, Marciniak R, Murawa P, Drews M and Jagodziński PP: Transcript level of AKR1C3 is down-regulated in gastric cancer. Biochem Cell Biol 94: 138-146, 2016.

18. Gan L, He J, Zhang X, Zhang YJ, Yu GZ, Chen Y, Pan J, Wang JJ and Wang $X$ : Expression profile and prognostic role of sex hormone receptors in gastric cancer. BMC Cancer 12: 566, 2012.

19. Tian Y, Wan H, Lin Y, Xie X, Li Z and Tan G: Androgen receptor may be responsible for gender disparity in gastric cancer. Med Hypotheses 80: 672-674, 2013.

20. Chomczynski P and Sacchi N: The single-step method of RNA isolation by acid guanidinium thiocyanate-phenol-chloroform extraction: Twenty-something years on. Nat Protoc 1: 581-585, 2006.

21. Tellmann G: The E-Method: A highly accurate technique for gene-expression analysis. Nature methods 3: i-ii, 2006.

22. Hashimoto T, Bazmi HH, Mirnics K, Wu Q, Sampson AR and Lewis DA: Conserved regional patterns of GABA-related transcript expression in the neocortex of subjects with schizophrenia. Am J Psychiatry 165: 479-489, 2008.

23. Rawłuszko AA, Antoniucci M, Horbacka K, Lianeri M, Krokowicz P and Jagodziński PP: Reduced expression of steroid sulfatase in primary colorectal cancer. Biomed Pharmacother 67: 577-582, 2013. 
24. Ruder HJ, Loriaux L and Lipsett MB: Estrone sulfate: Production rate and metabolism in man. J Clin Invest 51: 1020-1033, 1972.

25. Labrie F: Extragonadal synthesis of sex steroids: Intracrinology Ann Endocrinol (Paris) 64: 95-107, 2003.

26. Secky L, Svoboda M, Klameth L, Bajna E, Hamilton G, Zeillinger R, Jäger $\mathrm{W}$ and Thalhammer $\mathrm{T}$ : The sulfatase pathway for estrogen formation: Targets for the treatment and diagnosis of hormone-associated tumors. J Drug Deliv 2013: 957605: 2013.

27. Chetrite GS, Cortes-Prieto J, Philippe JC, Wright F and Pasqualini JR: Comparison of estrogen concentrations, estrone sulfatase and aromatase activities in normal, and in cancerous, human breast tissue samples. J Steroid Biochem Mol Biol 72: 23-27, 2000.

28. Utsumi T, Yoshimura N, Takeuchi S, Maruta M, Maeda K and Harada N: Elevated steroid sulfatase expression in breast cancers. J Steroid Biochem Mol Biol 73: 141-145, 2000.

29. Miyoshi Y, Ando A, Hasegawa S, Ishitobi M, Taguchi T, Tamaki Y and Noguchi S: High expression of steroid sulfatase mRNA predicts poor prognosis in patients with estrogen receptor-positive breast cancer. Clin Cancer Res 9: 2288-2293, 2003.

30. Suzuki T, Miki Y, Nakata T, Shiotsu Y, Akinaga S, Inoue K, Ishida T, Kimura M, Moriya T and Sasano H: Steroid sulfatase and estrogen sulfotransferase in normal human tissue and breast carcinoma. J Steroid Biochem Mol Biol 86: 449-454, 2003.

31. Poisson Paré D, Song D, Luu-The V, Han B, Li S, Liu G, Labrie F and Pelletier G: Expression of estrogen sulfotransferase 1E1 and steroid sulfatase in breast cancer: A immunohistochemical study. Breast Cancer (Auckl) 3: 9-21, 2009

32. Suzuki M, Ishida H, Shiotsu Y, Nakata T, Akinaga S, Takashima S, Utsumi T, Saeki T and Harada N: Expression level of enzymes related to in situ estrogen synthesis and clinicopathological parameters in breast cancer patients. J Steroid Biochem Mol Biol 113: 195-201, 2009

33. Hanamura T, Niwa T, Gohno $T$, Kurosumi M, Takei $H$, Yamaguchi Y, Ito $\mathrm{K}$ and Hayashi S: Possible role of the aromatase-independent steroid metabolism pathways in hormone responsive primary breast cancers. Breast Cancer Res Treat 143: 69-80, 2014.

34. Khvostova EP, Otpuschennikov AA, Pustylnyak VO and Gulyaeva LF: Gene expression of androgen metabolising enzymes in benign and malignant prostatic tissues. Horm Metab Res 47: $119-124,2015$

35. Montgomery RB, Mostaghel EA, Vessella R, Hess DL, Kalhorn TF, Higano CS, True LD and Nelson PS: Maintenance of intratumoral androgens in metastatic prostate cancer: A mechanism for castration-resistant tumor growth. Cancer Res 68: 4447-4454, 2008.

36. Chang KH, Ercole CE and Sharifi N: Androgen metabolism in prostate cancer: From molecular mechanisms to clinical consequences. Br J Cancer 111: 1249-1254, 2014

37. Saitoh Y, Sasano H, Naganuma H, Ohtani H, Sasano N, Ohuchi A and Matsuno S: De novo expression of aromatase in gastric carcinoma. Light and electron microscopic immunohistochemical and immunoblot study. Pathol Res Pract 188: 53-60, 1992

38. Izawa M, Inoue $\mathrm{M}$, Osaki $\mathrm{M}$, Ito $\mathrm{H}$, Harada T, Terakawa $\mathrm{N}$ and Ikeguchi M: Cytochrome P450 aromatase gene (CYP19) expression in gastric cancer. Gastric Cancer 11: 103-110, 2008.

39. Ueyama T, Shirasawa N, Numazawa M, Yamada K, Shelangouski M, Ito T and Tsuruo Y: Gastric parietal cells: Potent endocrine role in secreting estrogen as a possible regulator of gastro-hepatic axis. Endocrinology 143: 3162-3170, 2002

40. Ueyama T, Shirasawa N, Ito T and Tsuruo Y: Estrogen-producing steroidogenic pathways in parietal cells of the rat gastric mucosa. Life Sci 74: 2327-2337, 2004

41. Kobayashi H, Yoshida S, Sun YJ, Shirasawa N and Naito A $17 \beta$-Estradiol in the systemic circulation derives mainly from the parietal cells in cholestatic female rats. J Endocrinol Invest 39: 389-400, 2016.

42. Ozawa M, Takahashi K, Akazawa KH, Takashima T, Nagata H, Doi H, Hosoya T, Wada Y, Cui Y, Kataoka Y and Watanabe Y: PET of aromatase in gastric parietal cells using 11C-vorozole. J Nucl Med 52: 1964-1969, 2011.

43. Kobayashi H, Yoshida S, Sun YJ, Shirasawa N and Naito A: Postnatal development of gastric aromatase and portal venous estradiol-17ß levels in male rats. J Endocrinol 218: 117-124, 2013.

44. Kobayashi H, Yoshida S, Sun YJ, Shirasawa N and Naito A: Gastric estradiol-17ß (E2) and liver ER $\alpha$ correlate with serum E2 in the cholestatic male rat. J Endocrinol 219: 39-49, 2013
45. Pasqualini JR and Chetrite G: Paradoxical effect of estradiol: It can block its own bioformation in human breast cancer cells. J Steroid Biochem Mol Biol 78: 21-24, 2001.

46. Pasqualini JR and Chetrite GS: Estradiol as an anti-aromatase agent in human breast cancer cells. J Steroid Biochem Mol Biol 98: 12-17, 2006

47. Levin ER: Extranuclear steroid receptors are essential for steroid hormone actions. Annu Rev Med 66: 271-280, 2015.

48. Ur Rahman MS and Cao J: Estrogen receptors in gastric cancer: Advances and perspectives. World J Gastroenterol 22: 2475-2482, 2016.

49. Hayashi SI, Eguchi H, Tanimoto K, Yoshida T, Omoto Y, Inoue A, Yoshida N and Yamaguchi Y: The expression and function of estrogen receptor alpha and beta in human breast cancer and its clinical application. Endocr Relat Cancer 10: 193-202, 2003.

50. Shanle EK and Xu W: Selectively targeting estrogen receptors for cancer treatment. Adv Drug Deliv Rev 62: 1265-1276, 2010.

51. Xie LQ, Yu JP and Luo HS: Expression of estrogen receptor beta in human colorectal cancer. World J Gastroenterol 10: 214-217, 2004.

52. Risbridger GP, Davis ID, Birrell SN and Tilley WD: Breast and prostate cancer: More similar than different. Nat Rev Cancer 10: 205-212, 2010.

53. Chandanos E, Rubio CA, Lindblad M, Jia C, Tsolakis AV, Warner M, Gustafsson JA and Lagergren J: Endogenous estrogen exposure in relation to distribution of histological type and estrogen receptors in gastric adenocarcinoma. Gastric Cancer 11: $168-174,2008$.

54. Kameda C, Nakamura M, Tanaka H, Yamasaki A, Kubo M, Tanaka M, Onishi H and Katano M: Oestrogen receptor-alpha contributes to the regulation of the hedgehog signalling pathway in ERalpha-positive gastric cancer. Br J Cancer 102: 738-747, 2010.

55. Xu CY, Guo JL, Jiang ZN, Xie SD, Shen JG, Shen JY and Wang LB: Prognostic role of estrogen receptor alpha and estrogen receptor beta in gastric cancer. Ann Surg Oncol 17: 2503-2509, 2010.

56. Deng H, Huang X, Fan J, Wang L, Xia Q, Yang X, Wang Z and Liu L: A variant of estrogen receptor-alpha, ER-alpha36 is expressed in human gastric cancer and is highly correlated with lymph node metastasis. Oncol Rep 24: 171-176, 2010.

57. Liu S, He L, Wang Z and Wen G: Expression of sex hormone receptor in gastric cancer with synchronous ovarian metastasis and its significance. Zhonghua Yi Xue Za Zhi 94: 1861-1865, 2014 (In Chinese)

58. Järvinen TA, Pelto-Huikko M, Holli K and Isola J: Estrogen receptor beta is coexpressed with ERalpha and PR and associated with nodal status, grade, and proliferation rate in breast cancer. Am J Pathol 156: 29-35, 2000.

59. Zhu X, Leav I, Leung YK, Wu M, Liu Q, Gao Y, McNeal JE and Ho SM: Dynamic regulation of estrogen receptor-beta expression by DNA methylation during prostate cancer development and metastasis. Am J Pathol 164: 2003-2012, 2004.

60. Wang M, Pan JY, Song GR, Chen HB, An LJ and Qu SX: Altered expression of estrogen receptor alpha and beta in advanced gastric adenocarcinoma: Correlation with prothymosin alpha and clinicopathological parameters. Eur J Surg Oncol 33: 195-201, 2007.

61. Ryu WS, Kim JH, Jang YJ, Park SS, Um JW, Park SH, Kim SJ, Mok YJ and Kim CS: Expression of estrogen receptors in gastric cancer and their clinical significance. J Surg Oncol 106: 456-461, 2012.

62. Matsuyama S, Ohkura Y, Eguchi H, Kobayashi Y, Akagi K, Uchida K, Nakachi K, Gustafsson JA and Hayashi S: Estrogen receptor beta is expressed in human stomach adenocarcinoma. J Cancer Res Clin Oncol 128: 319-324, 2002.

63. Guo JL, Xu CY, Jiang ZN, Dong MJ, Xie SD, Shen JG, Cao J and Wang LB: Estrogen receptor beta variants mRNA expressions in gastric cancer tissue samples and association with clinicopathologic parameters. Hepatogastroenterology 57: 1584-1588, 2010.

64. Zhou J, Teng R, Xu C, Wang Q, Guo J, Xu C, Li Z, Xie S, Shen J and Wang L: Overexpression of ER $\alpha$ inhibits proliferation and invasion of MKN28 gastric cancer cells by suppressing $\beta$-catenin. Oncol Rep 30: 1622-1630, 2013.

65. Kominea A, Konstantinopoulos PA, Kapranos N, Vandoros G, Gkermpesi M, Andricopoulos P, Artelaris S, Savva S, Varakis I, Sotiropoulou-Bonikou G and Papavassiliou AG: Androgen receptor (AR) expression is an independent unfavorable prognostic factor in gastric cancer. J Cancer Res Clin Oncol 130: 253-258, 2004 
66. Zhang BG, Du T, Zang MD, Chang Q, Fan ZY, Li JF, Yu BQ, Su LP, Li C, Yan C, et al: Androgen receptor promotes gastric cancer cell migration and invasion via AKT-phosphorylation dependent upregulation of matrix metalloproteinase 9. Oncotarget 5: 10584-10595, 2014.

67. Bjerregaard-Olesen C, Ghisari M, Kjeldsen LS, Wielsøe M and Bonefeld-Jørgensen EC: Estrone sulfate and dehydroepiandrosterone sulfate: Transactivation of the estrogen and androgen receptor. Steroids 105: 50-58, 2016.

68. McKenna NJ, Lanz RB and O'Malley BW: Nuclear receptor coregulators: Cellular and molecular biology. Endocr Rev 20: 321-344, 1999.

69. Wang W, Song XW, Bu XM, Zhang N and Zhao CH: PDCD2 and NCoR1 as putative tumor suppressors in gastric gastrointestinal stromal tumors. Cell Oncol (Dordr) 39: 129-137, 2016

70. Kershah SM, Desouki MM, Koterba KL and Rowan BG: Expression of estrogen receptor coregulators in normal and malignant human endometrium. Gynecol Oncol 92: 304-313, 2004.

71. Zhang Z, Yamashita H, Toyama T, Sugiura H, Ando Y, Mita K, Hamaguchi M, Hara Y, Kobayashi S and Iwase H: NCOR1 mRNA is an independent prognostic factor for breast cancer. Cancer Lett 237: 123-129, 2006.

72. Gallardo F, Padrón A, Garcia-Carbonell R, Rius C, González-Perez A, Arumí-Uria M, Iglesias M, Nonell L, Bellosillo B, Segura S, et al: Cytoplasmic accumulation of NCoR in malignant melanoma: Consequences of altered gene repression and prognostic significance. Oncotarget 6: 9284-9294, 2015

73. Kashima H, Horiuchi A, Uchikawa J, Miyamoto T, Suzuki A, Ashida T, Konishi I and Shiozawa T: Up-regulation of nuclear receptor corepressor (NCoR) in progestin-induced growth suppression of endometrial hyperplasia and carcinoma. Anticancer Res 29: 1023-1029, 2009.

74. Boorjian SA, Heemers HV, Frank I, Farmer SA, Schmidt LJ, Sebo TJ and Tindall DJ: Expression and significance of androgen receptor coactivators in urothelial carcinoma of the bladder. Endocr Relat Cancer 16: 123-137, 2009.

75. Berns EM, van Staveren IL, Klijn JG and Foekens JA: Predictive value of SRC-1 for tamoxifen response of recurrent breast cancer. Breast Cancer Res Treat 48: 87-92, 1998.
76. Fleming FJ, Myers E, Kelly G, Crotty TB, McDermott EW, O'Higgins NJ, Hill AD and Young LS: Expression of SRC-1, AIB1, and PEA3 in HER2 mediated endocrine resistant breast cancer; a predictive role for SRC-1. J Clin Pathol 57: 1069-1074, 2004.

77. Wang S, Yuan Y, Liao L, Kuang SQ, Tien JC, O'Malley BW and $\mathrm{Xu}$ J: Disruption of the SRC-1 gene in mice suppresses breast cancer metastasis without affecting primary tumor formation. Proc Natl Acad Sci USA 106: 151-156, 2009.

78. Qin L, Chen X, Wu Y, Feng Z, He T, Wang L, Liao L and Xu J: Steroid receptor coactivator-1 upregulates integrin $\alpha_{5}$ expression to promote breast cancer cell adhesion and migration. Cancer Res 71: 1742-1751, 2011

79. Xu Y, Hu B, Qin L, Zhao L, Wang Q, Wang Q, Xu Y and Jiang J: SRC-1 and Twist1 expression positively correlates with a poor prognosis in human breast cancer. Int J Biol Sci 10: 396-403, 2014.

80. Qin L, Wu YL, Toneff MJ, Li D, Liao L, Gao X, Bane FT, Tien JC, Xu Y, Feng Z, et al: NCOA1 Directly Targets M-CSF1 Expression to Promote Breast Cancer Metastasis. Cancer Res 74: 3477-3488, 2014.

81. Qin L, Xu Y, Xu Y, Ma G, Liao L, Wu Y, Li Y, Wang X, Wang X, Jiang $\mathrm{J}$, et al: NCOA1 promotes angiogenesis in breast tumors by simultaneously enhancing HIF1 $\alpha$ - and AP-1-mediated VEGFa transcription. Oncotarget 6: 23890-23904, 2015.

82. Flågeng MH, Moi LL, Dixon JM, Geisler J, Lien EA, Miller WR, Lønning PE and Mellgren G: Nuclear receptor co-activators and HER-2/neu are upregulated in breast cancer patients during neo-adjuvant treatment with aromatase inhibitors. Br J Cancer 101: 1253-1260, 2009.

83. Tai H, Kubota $\mathrm{N}$ and Kato S: Involvement of nuclear receptor coactivator SRC-1 in estrogen-dependent cell growth of MCF-7 cells. Biochem Biophys Res Commun 267: 311-316, 2000.

84. Culig Z, Comuzzi B, Steiner H, Bartsch G and Hobisch A: Expression and function of androgen receptor coactivators in prostate cancer. J Steroid Biochem Mol Biol 92: 265-271, 2004. 